NATIONAL LABORATORY MANAGED BY UT-BATTELLE FOR. THE DEPARTMENT OF ENERGY

Metals and Ceramics Division

CRADA Final Report

For

CRADA Number ORNL99-0533

DEVELOPMENT OF LOW-COST

AUSTENITIC STAINLESS GAS-TURBINE

AND DIESEL ENGINE COMPONENTS WITH

ENHANCED HIGH-TEMPERATURE

RELIABILITY

P. J. Maziasz and R. W. Swindeman

Oak Ridge National Laboratory

P. F. Browning

Solar Turbines, Inc.

M. E. Frary, M. J. Pollard, C. W. Siebenaler, and T.E. McGreevy*

Caterpillar, Inc.

*(formerly with Caterpillar, currently with

Bradley University)

Prepared by

Oak Ridge National Laboratory

Oak Ridge, TN 37831

managed by

UT-Batitelie, LLC

for the

U.S. Department of Energy

under contract DE-AC05-00OR22725

Approved for Public Release

Unlimited Distribution 


\section{DOCUMENT AVAILABILITY}

Reports produced after January 1, 1996, are generally available free via the U.S. Department of Energy (DOE) Information Bridge.

Web site http://www.osti.gov/bridge

Reports produced before January 1,1996 , may be purchased by members of the public from the following source.

National Technical Information Service

5285 Port Royal Road.

Springfield, VA 22161

Telephone 703-605-6000 (1-800-553-6847)

TDD 703-487-4639

Fax 703-605-6900

E-mail info@ntis.fedworld.gov

Web site http://www.ntis.gov/support/ordernowabout.htm

Reports are available to DOE employees, DOE contractors,

Energy Technology Data Exchange (ETDE) representatives, and International Nuclear Information System (INIS) .

representatives from the following source.

Office of Scientific and Technical Information

P.O. Box 62

Oak Ridge, TN 37831

Telephone 865-576-8401

Fax 865-576-5728

E-mail reports@adonis.osti.gov

Web site http://www.osti.gov/contact.html

This report was prepared as an account of work sponsored by an agency of the United States Government. Neither the United States Government nor any agency thereof, nor any of their employees, makes any warranty, express or implied, or assumes. any legal-liability or responsibility for the accuracy, completeness, or usefulness of any information, apparatus, product, or process disclosed, or represents that its use would not infringe privately owned rights. Reference herein to any specific commercial product, process, or service by trade name, trademark, manufacturer, or otherwise, does not necessarily constitute or imply its endorsement, recommendation, or favoring by the United States Government or any agency thereof. The views and opinions of authors expressed herein do not necessarily state or reflect those of the United States Government or any agency thereof. 
C/ORNL99-0533

Metals and Ceramics Division

CRADA Final Report For CRADA Number ORNL99-0533

DEVELOPMENT OF LOW-COST AUSTENITIC STAINLESS GAS-TURBINE AND DIESEL ENGINE COMPONENTS WITH ENHANCED HIGHTEMPERATURE RELIABILITY

\author{
P. J. Maziasz and R. W. Swindeman \\ Oak Ridge National Laboratory \\ P. F. Browning \\ Solar Turbines, Inc.
}

M. E. Frary, M. J. Pollard, C. W. Siebenaler, and T. E. McGreevy* Caterpillar, Inc.

*(formerly with Caterpillar, currently with Bradley University)

Prepared by Oak Ridge National Laboratory Oak Ridge, TN 37831 managed by UT-Battelle, LLC for the U.S. Department of Energy under contract DE-AC0500OR22725

Approved for Public Release Unlimited Distribution

Research was supported through a CRADA with Solar Turbines, Inc. and with Caterpillar, Inc., sponsored by the U.S. Department of Energy, Assistant Secretary for Energy Efficiency and Renewable Energy, and Distributed Energy Resources Materials Program, Heavy Vehicle Propulsion Materials Program, under contract DE-AC05-00OR22725 with Oak Ridge National Laboratory, managed by UT-Battelle, LLC. 



\title{
DEVELOPMENT. OF LOW-COST AUSTENITIC STAINLESS GAS-TURBINE AND DIESEL ENGINE COMPONENTS WITH ENHANCED HIGH-TEMPERATURE RELIABILITY
}

\author{
CRADA No. ORNL99-0533 \\ between \\ Oak Ridge National Laboratory \\ and \\ Caterpillar, Inc.
}

\begin{abstract}
In July of 1999, a Cooperative Research and Development Agreement (CRADA) was undertaken between Oak Ridge National Laboratory (ORNL) and Solar Turbines, Inc. and Caterpillar, Inc. (Caterpillar Technical Center) to evaluate commercial cast stainless steels for gas turbine engine and diesel engine exhaust component applications relative to the materials currently being used. If appropriate; the goal was to develop cast stainless steels with improved performance and reliability rather than switch to more costly cast Ni-based superalloys for upgraded performance.
\end{abstract}

The gas-turbine components considered for the Mercury-50 engine were the combustor housing and end-cover, and the center-frame hot-plate, both made from commercial CF8C cast austenitic stainless steel $(\mathrm{Fe}-19 \mathrm{Cr}-12 \mathrm{Ni}-\mathrm{Nb}, \mathrm{C})$, which is generally limited to use at below $650^{\circ} \mathrm{C}$. The advanced diesel engine components considered for truck applications (C10, C12, 3300 and 3400) were the exhaust manifold and turbocharger housing made from commercial high SiMo ductile cast iron with uses limited to $700-750^{\circ} \mathrm{C}$ or below.

Shortly after the start of the CRADA, the turbine materials emphasis changed to wrought $347 \mathrm{H}$ stainless steel (hot-plate) and after some initial baseline tensile and creep testing, it was confirmed that this material was typical of those comprising the abundant database, and by 2000 , the emphasis of the CRADA was primarily on diesel engine materials. For the diesel applications, commercial SiMo cast iron and standard cast CN12 austenitic stainless steel (Fe$25 \mathrm{Cr}-13 \mathrm{Ni}-\mathrm{N} \mathrm{V}, \mathrm{C}, \mathrm{N}, \mathrm{S})$ baseline materials were obtained commercially. Tensile and creep testing from room temperature to $900^{\circ} \mathrm{C}$ showed the CN12 austenitic stainless steel to have far superior strength compared to SiMo cast iron above $550^{\circ} \mathrm{C}$, together with outstanding oxidation resistance. However, aging at $850^{\circ} \mathrm{C}$ reduced room-temperature ductility of the standard CN12, and creep-rupture resistance at $850^{\circ} \mathrm{C}$ was less than expected, which triggered a focused laboratory-scale alloy development effort on modified cast austenitic stainless steels at ORNL. Isothermal fatigue testing at $700^{\circ} \mathrm{C}$ also showed that standard CN12 was far superior to SiMo cast iron, but somewhat less than the desired behavior.

During the first year, 3 new modified CF8C heats and 8 new modified CN12 heats were made, based on compositional changes specifically designed to change the nature, dispersion and stability of the as-cast and high-temperature aging-induced microstructures that consisted of carbides and other precipitate phases. Screening of the alloys at room-temperature and at $850^{\circ} \mathrm{C}$ (tensile and creep-rupture) showed a ten-fold increase in rupture life of the best modified CN12 
relative to the baseline material, better room-temperature ductility after aging, caused by less precipitation in the as-cast material and much less aging-induced precipitation. The best new modified CF8C steel showed strength at tensile and creep-rupture strength comparable to standard $\mathrm{CN} 12$ steel at $850^{\circ} \mathrm{C}$, due to a unique and very stable microstructure. The CRADA was scheduled to end in July 2001, but was extended twice until July, 2002. Based on the very positive results on the newly developed modified CF8C and CN12 cast austenitic stainless steels, a new CRADA with Caterpillar has been set up to commercially scale-up, test and evaluate, and make trial components from the new steels.

\section{Objectives}

One objective of this work was to evaluate cast austenitic stainless steels as a high-performance alternative to SiMo ductile cast iron, which is currently the standard material used in most diesel engines for exhaust manifold and turbocharger housing components. The new material must be able to withstand prolonged exposure at temperatures of $750^{\circ} \mathrm{C}$ or above, as well as to survive the severe thermal cycling from near room-temperature to such high-temperatures without developing cracks. Another objective of this CRADA was to cast stainless steels with more performance above $650^{\circ} \mathrm{C}$ for gas-turbine exhaust or hot structural components. This project has tested commercially available cast alloys, as well as developed new, modified cast alloys with significantly enhanced performance relative to the baseline materials for both gas-turbine and diesel-engine applications. Ultimately, this project was to provide high-performance, reliable materials that were also cost-effective for such applications. The alloying modifications that significantly boost performance of the modified cast stainless steels should not increase alloy cost. This large CRADA project was blended together from two different DOE programs to take advantage of the similar cast materials objectives for both advanced gas-turbine engines as well as advanced diesel engines at Caterpillar and Solar Turbines.

\section{Benefits to DOE Mission}

This program directly benefited the ATS program by providing a cost-effective modified cast CF8C stainless steel that will enable gas-turbines to withstand higher exhaust temperatures, which leads to higher efficiency and lower emissions. The OTT HVPM program also directly benefits from the improved modified CF8C and CN12 stainless steels that withstand higher engine temperatures that enable better fuel efficiency and lower emissions, as well as meet the need of the engine makers to dramatically extend component lifetime (normally increased temperature and increased lifetime are trade-offs). There is a general, indirect benefift to other DOE programs that deal with improving high temperature materials performance because the alloy development concepts based on microstructural design and control transfer to other kinds of wrought or cast stainless steels or alloys.

\section{Technical Discussion of Work Performed}

The work performed on this CRADA was organized and separated into three phases to achieve the objectives, several of which ran in parallel. The first phase of the work was testing and evaluation of candidate gas-turbine hot component materials for use at about $650^{\circ} \mathrm{C}$. The second phase of work was testing and evaluation of current and baseline advanced materials for diesel engine exhaust components for use above $750^{\circ} \mathrm{C}$. The third phase of the work was 
microstructural characterization to understand the high-temperature performance of current commercial materials, and then alloy development based on design and control of hightemperature microstructural evolution, if appropriate.

\section{Testing and Evaluation for Gas Turbine Components}

Commercial centifugially-cast CF8C austenitic stainless steel was used for the combuistor housing and end-cover of the advanced gas-turbine engine, and at the beginning of the project, upgraded performance of these components was not needed. Initially, cast CF8C was evaluated for the center-frame hot-plate of the gas-turbine engine, but a design change was made to wrought 347 stainless steel for that application. Preliminary testing of the $347 \mathrm{H}$ stainless steel included tensile testing from room temperature to $700^{\circ} \mathrm{C}$, the effects of short-term aging at $650^{\circ} \mathrm{C}$, and creep testing at $600-700^{\circ} \mathrm{C}$, with some isothermal fatigue testing to follow. The initial testing showed data consistent with well established data bases for 347 stainless steel, and it was decided that there was little need for further testing.

\section{Testing and Evaluation for Diesel Engine Exhaust Components}

Commercial cast $\mathrm{CN} 12$ austenitic stainless steel (Fe-25Cr-13Ni-1.8Nb, C, N, S) was chosen as the baseline alloy for evaluation relative to SiMo ductile cast iron. Materials were evaluated in the as-cast condition as well as after appropriate thermal aging at temperatures up to $850^{\circ} \mathrm{C}$. Tensile and cyclic isothermal fatigue properties were evaluated selectively from room temperature up to $900^{\circ} \mathrm{C}$, together with some high-temperature creep-rupture and oxidation/corrosion testing. Microstructure analysis was performed on some of the CN12 specimeris to better understand mechanisms associated with their properties changes.

Tensile testing of as-cast materials showed that the baseline standard CN12 was much stronger than SiMo cast iron at $500-550^{\circ} \mathrm{C}$ and above, as indicated in Figure 1. This difference in high temperature strength made it dificult to creep-rupture test the two materials at the same conditions, so SiMo cast iron was creep-tested at $550-650^{\circ} \mathrm{C}$, and the baseline CN12 was creeptested at $750-900^{\circ} \mathrm{C}$. The data are plotted together using creep-stress versus the Larson-Miller parameter (with takes into account test temperature and rupture time) in Figure 2. The cast CN12 has an overwhelming strength advantage over SiMo cast iron, which becomes very weak $600-650^{\circ} \mathrm{C}$. High-cyclè fatigue testing was also done on both the SiMto cast iron and the standard baseline CN12, because cracking during severe thermal cycling is life-limiting failure for exhaust manifolds. While both materials have comparable fatigue resistance at roomtemperature, the fatigue resistance of the $\mathrm{CN} 12$ steel is superior to that of SiMo cast iron at $700^{\circ} \mathrm{C}$. 


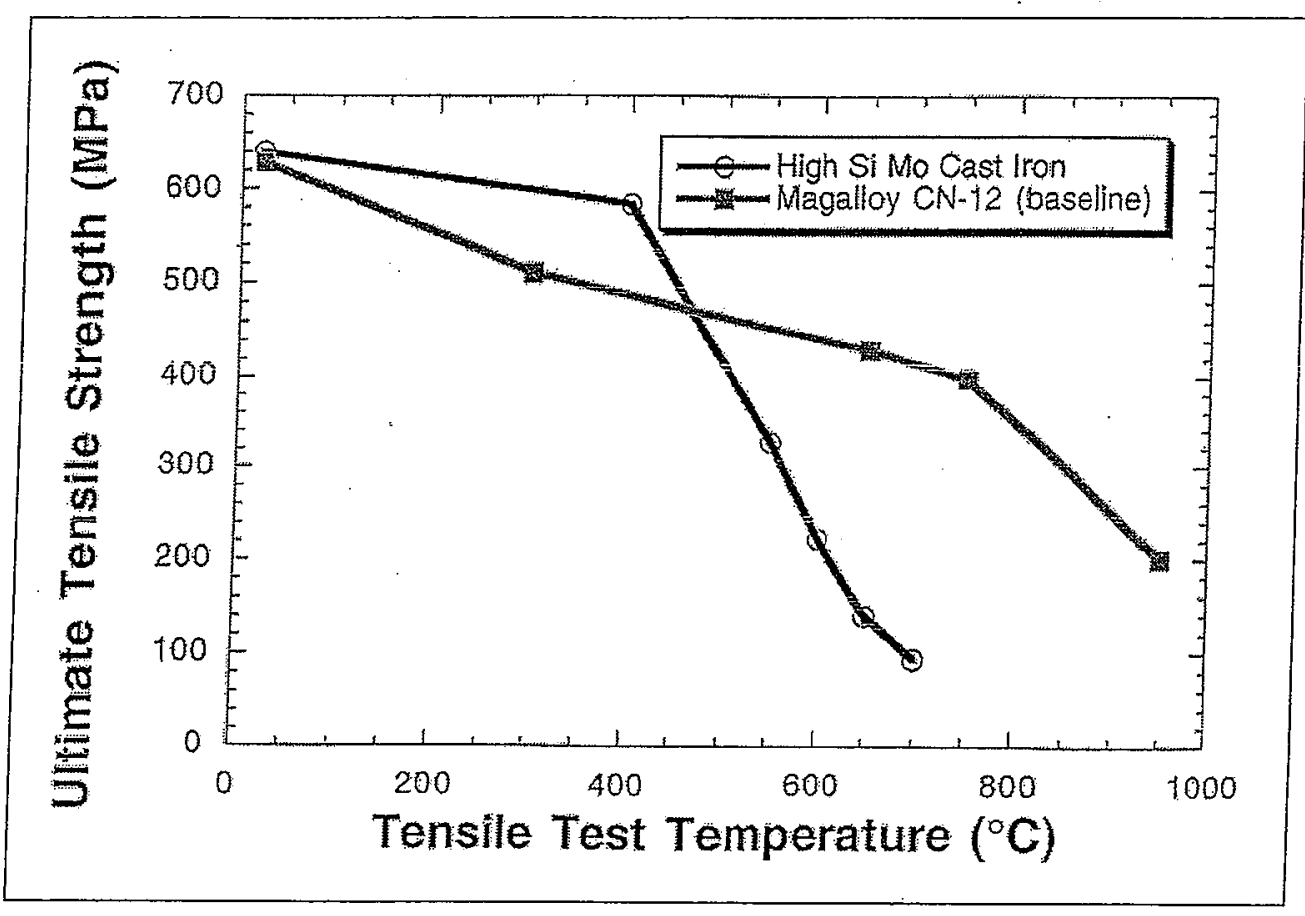

Fig. 1 - Plots of ultimate tensile strength versus test temperature for commercial SiMo cast iron and a commercial standard (baseline) $\mathrm{CN}-12$ cast austenitic stainless steel.

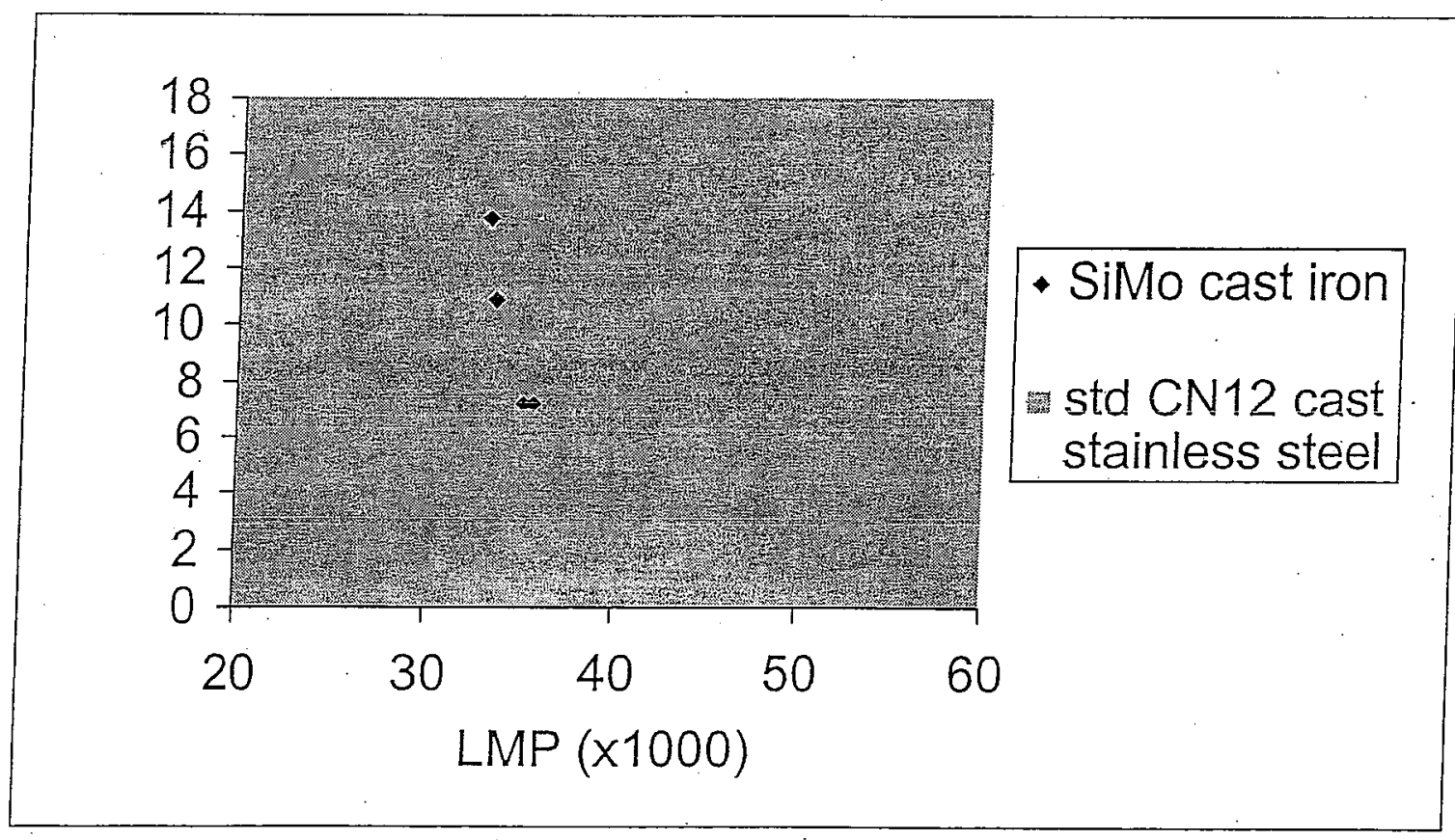

Fig. 2 - A plot of Larson-Miller Parameter $\left(L M P,=(T+460)\left(20+\log t_{\mathrm{T}}\right)\right.$, where $\mathrm{T}$ is creep test temperature in ${ }^{\circ} \mathrm{F}$ and $t_{T}$ is the time to rupture in hours) versus creep-rupture stress (vertical axis in $\mathrm{ksi}$ ) for various creep tests run on SiMo cast iron $\left(550-650^{\circ} \mathrm{C}\right)$ and commercial $\mathrm{CN}-12$ cast austenitic stainless steel $\left(750-900^{\circ} \mathrm{C}\right)$. Cast $\mathrm{CN}-12$ austenitic stainless steel has an overwhelming creep strength advantage over SiMo cast iron. 


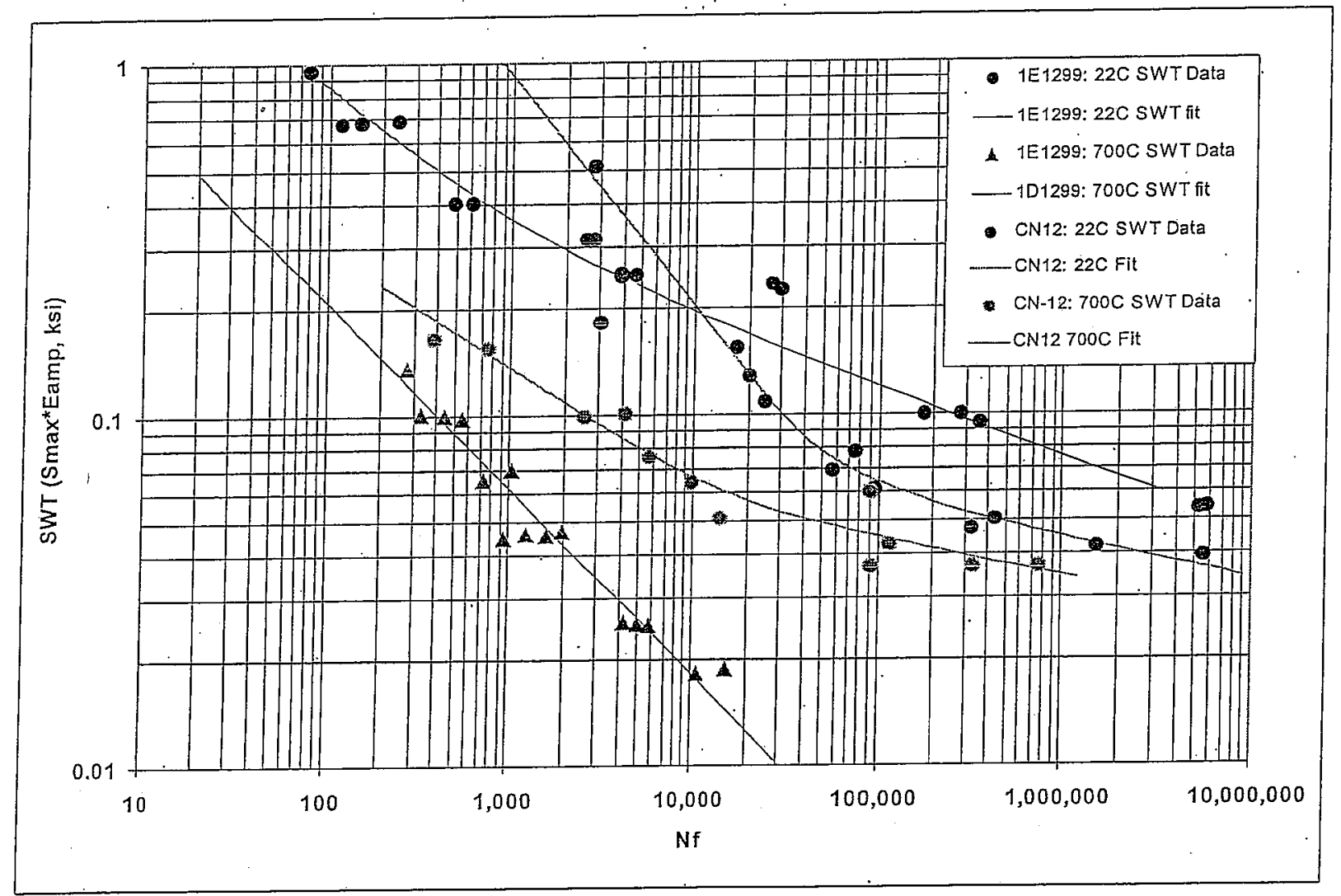

Fig. 3 A plot of the Smith-Watson-Topper (SWT) parameter (maximum stress X strain amplitude of the fatigue stress-strain loop) versus number of cycles to fracture for fatigue tests of SiMo cast iron and $\mathrm{CN} 12$ cast austenitic stainless steel isothermally fatigue tested at room temperature and at $700^{\circ} \mathrm{C}$ in air. At $700^{\circ} \mathrm{C}$, the $\mathrm{CN} 12$ is approaching an endurance limit, and is significantly more resistant to fatigue than SiMo cast iron. 


\section{Alloy Development of Cast Austenitic Stainless Steels for Improved High-Temperature Strength and Aging Resistance}

Aging at $850^{\circ} \mathrm{C}$ for $10-1000 \mathrm{~h}$ significantly reduced the room temperature ductility of the CN12 relative to unaged material, and the creep-rupture life and ductility at high stresses at $850^{\circ} \mathrm{C}$ were lower than expected, revealed significant reduction in the fracture ductility of standard baseline CN12. Therefore, a parallel alloy development effort to improve these properties was undertaken in 2000, because this was considered important to providing a cast stainless steel that could resist severe thermal cycling and improved high temperature performance and reliability.

Eight smaller heats (15 lbs each) of modified CN12 austenitic stainless steels were produced at ORNL and evaluated. Preliminary screening of as-cast or cast and aged material with tensile testing (room temperature and $850^{\circ} \mathrm{C}$ ), and of as-cast material with creep-rupture testing at $850^{\circ} \mathrm{C}$ indicates that significant improvements have been achieved in high-temperature strength and aging resistance. The improvements of the best modified $\mathrm{CN}-12$ alloys for creep-rupture testing at $850^{\circ} \mathrm{C}$ and $110 \mathrm{MPa}$ relative to the standard commercial $\mathrm{CN}-12$ alloy are shown in Figure 4. The best second-round modified $\mathrm{CN}-12$ alloy is almost ten times better than the standard material. Modified $\mathrm{CN} 12$ alloys produced by two other commercial casters were also tested, with the alloy from one vendor being no different than the standard CN12 baseline material, and the alloy from the other vendor being too brittle to load and test at these conditions. Microstructural analysis indicates the modified $\mathrm{CN} 12$ steels have less precipitation in the as-cast condition, and much less after aging at $800-850^{\circ} \mathrm{C}$, than the baseline material.

In addition similar alloy development efforts were made on the less costly and more castable CF8C stainless steel, which has been considered as a candidate for diesel exhaust applications based on its oxidation resistance, but not chosen because it lacks strength above $650^{\circ} \mathrm{C}$. Three smaller heats of modified CF8C were made at ORNL (one baseline unmodified alloy and two modified alloys) and screened using the same tensile tests and creep-rupture testing at $850^{\circ} \mathrm{C}$ used for the CN12 steels. The best modified CF8C showed high temperature strength comparable to standard baseline $\mathrm{CN} 12$ steel, and at room-temperature showed much more ductility in the as-cast and as-cast plus aged condition. The dramatic improvements in creepresistance of the modified CF8C alloys at $850^{\circ} \mathrm{C}$ relative to commercial material is shown in Figure 5. One of the new modified CF8C steels failed after almost $13,000 \mathrm{~h}$ with about $12-15 \%$ ductility, whereas the other modified. CF8C steel has not failed after more than $20,000 \mathrm{~h}$ of testing, and shows only about $1 \%$ strain. Both modified $\mathrm{CF} 8 \mathrm{C}$ steels are several orders of magnitude better than the commercial CF8C steel. Microstructurally, the modified CF8C steel has much less precipitation in the as-cast condition than any of the standard baseline or modified $\mathrm{CN} 12$ steels, and aging at $800-850^{\circ} \mathrm{C}$ produces little additional precipitation.

\section{Inventions}

An invention disclosure and patent application on cast austenitic stainless alloys with improved performance were completed by Caterpillar and filed with the U.S. Patent Office. It was entitled "Heat and Corrosion Resistant Cast Stainless Steels With Improved High Temperature Strength and Ductility;" by P.J. Maziasz (ORNL), T. McGreevy (U. of Bradley/CAT), M.J. Pollard 
(CAT), C.W. Siebenaler (CAT), and R.W. Swindeman (ORNL). Recently, that original patent has been divided into two applications, with one covering the new, modified $\mathrm{CN} 12$ stainless steels, and the other covering the new, modified. CF8C stainless steels.

\section{Commercialization Possibilities}

There was been interest expressed by the engine divisions within Caterpillar and by Solar Turbines in pursuing commercial scale-up of these new, modified cast austenitic stainless steels. A highlight on this project entitled "Cast Stainless Steels are Stronger at Higher Temperatures," was published in ASM Advanced Materials and Processes magazine in January, 2002 (vol. 160, no.1, p. 13). Several companies have expressed interest in these materials. At the conclusion of this CRADA, Caterpillar has begun discussions and interactions with two companies that are capable of scaled-up casting and of making cast stainless steel engine components.

\section{Plans for Future Collaboration}

Prior to the end of this current.CRADA, a new three-year CRADA has been developed and approved entitled "Advanced Cast Austenitic Stainless Steels for High Temperature Components," between Caterpillar, Inc. and ORNL. (CRADA No. ORNL 02-0658). Its objective is to commercially scale up the most promising heats of new modified CF8C and CN12 stainless steels; to test more thoroughly tensile, creep, fatigue and thermal fatigue properties, and to make and evaluate trial engine components. 


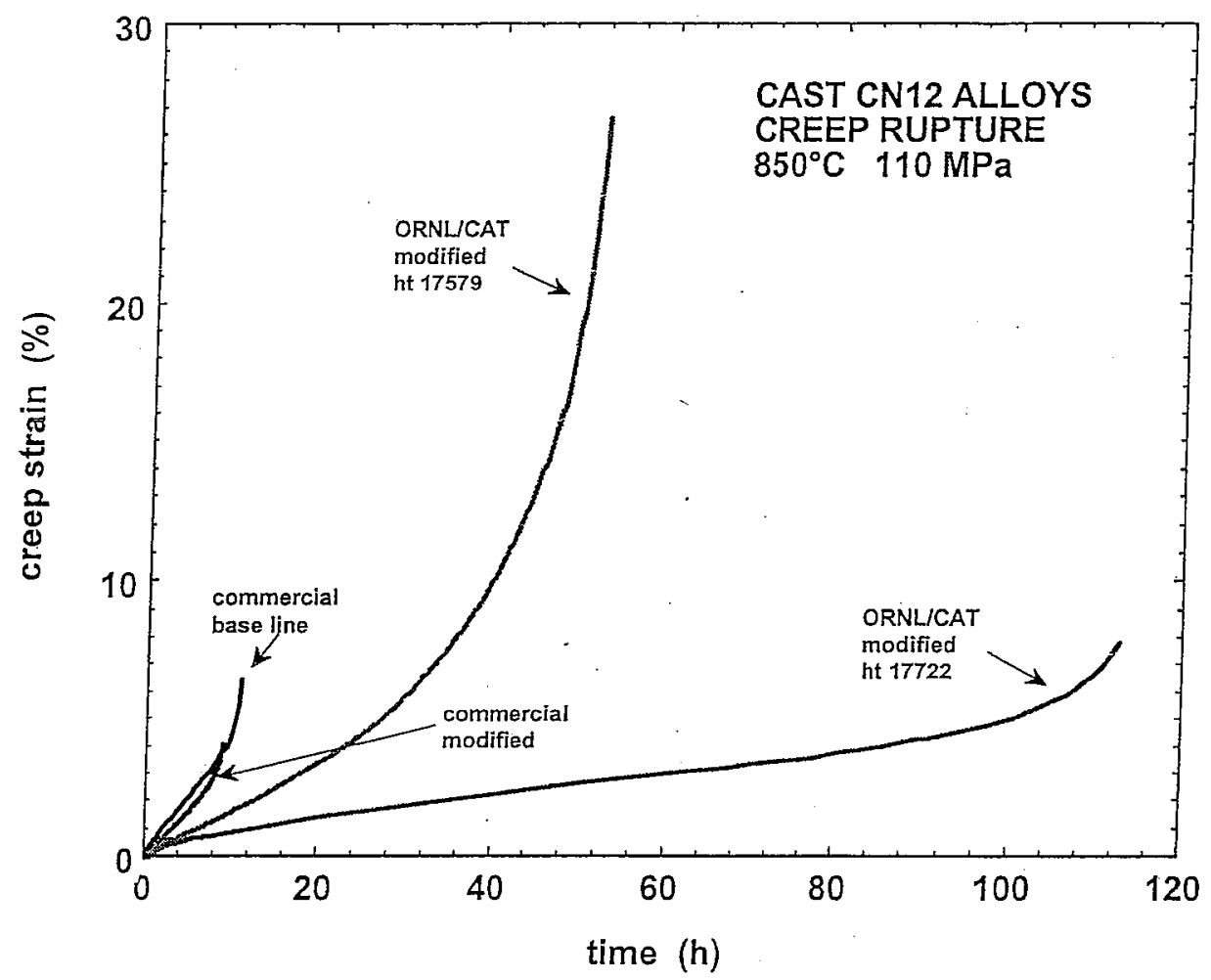

Fig. 4 - Creep-rupture curves of creep-strain versus rupture time for a commercial standard (baseline) and modified heats of $\mathrm{CN}-12$ cast austenitic stainiess steel, and the two best laboratory heats from two rounds of alloy modifications of $\mathrm{CN}-12$ steel developed by ORNL and Caterpillar. 


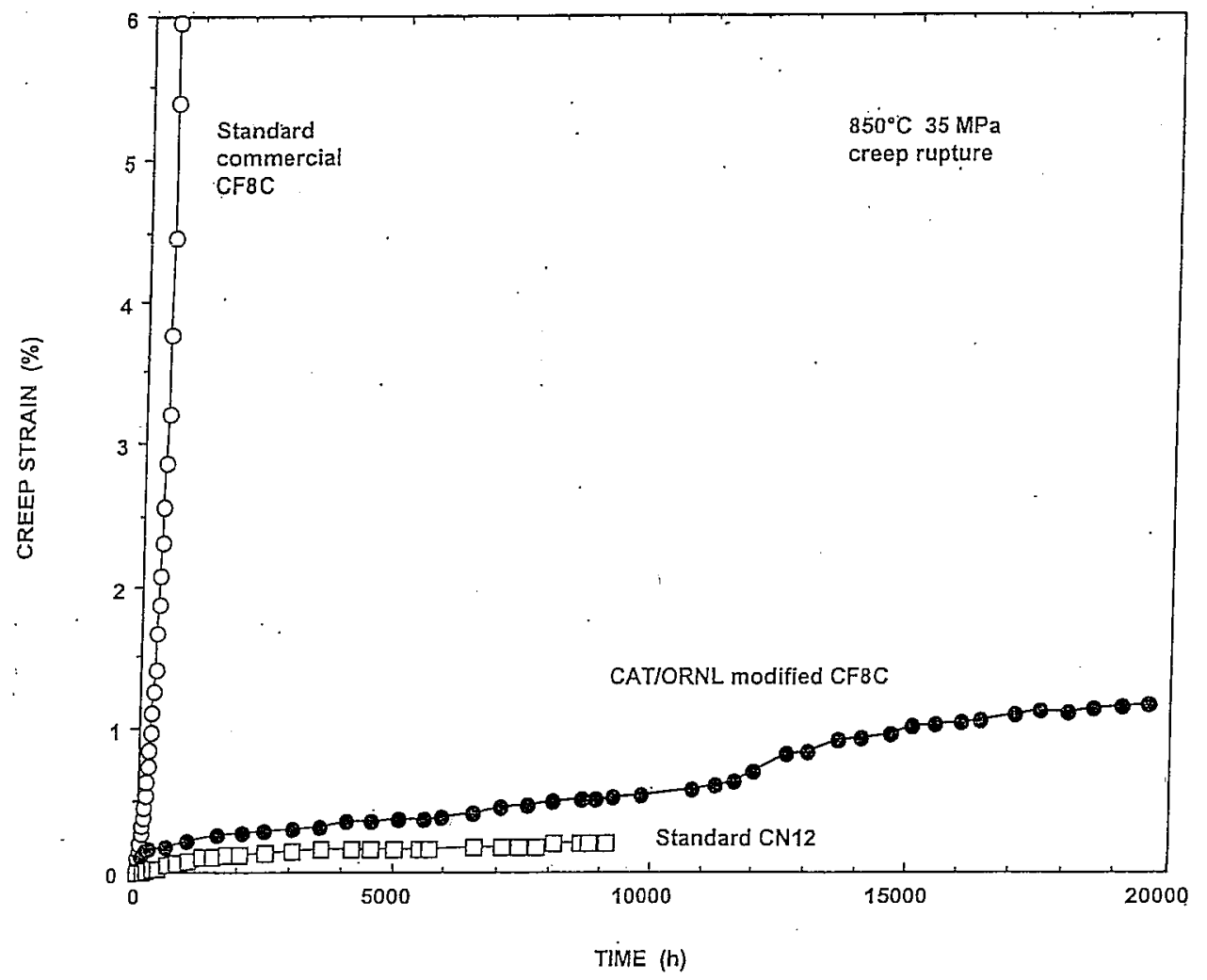

Fig. 5 - Creep-rupture curves of creep-strain versus rupture time for a commercial heat of standard CF8C cast austenitic stainless steel and the best labboratory heat of modified CF8C cast austenitic stainless steel. Creep-rupture tests of the best modified CF8C steels and the standard, baseline CN12 steel had not failed at the end of the CRADA.

\section{Conclusions}

Standard cast CN12 austenitic stainless steel has significant advantages in strength, creep and fatigue resistance relative to SiMo cast iron at $500-550^{\circ} \mathrm{C}$ and above. A modified $\mathrm{CN}$ i12 steel has been developed with better strength, more ductility and better aging resistance than standard $\mathrm{CN} 12$ at $700-850^{\circ} \mathrm{C}$. A modified CF8C steel had been developed that has strength comparable to standard CN12 steel, but with much more ductility and much better aging resistance at 700$850^{\circ} \mathrm{C}$. Such properties improvements are believed to be important to ressistance to cracking during severe thermal cycling and fatigue.

\section{Acknowledgements}

Significant contributions to the CRADA work were made by Christopher O. Stevens (tensile testing), Ralph L. Martin (fatigue testing), Hu F. Longmire (metallographic analysis), Joseph D. Vought (alloy casting), and J. Wade Jones (preparation of specimens for transmission and 
analytical electron microscopy) at ORNL. Particular thanks to D. Ray Johnson, Manager Heavy Vehicle Propulsion Materials program at ORNL, and Sidney Diamond, Manager - Heavy Vehicle Propulsion Materials, Office of Transportation Technologies, under the Assistant Secretary for Energy Efficiency and Renewable Energy at the U.S. Department of Energy for their funding support and technical interest in this project. Thanks also to Michael J. Readey, Manager of Advanced Materials Technology at the Caterpillar Technical Center for his support and encouragement. 


\section{DISTRIBUTION}

Internal Distribution

1. E. E. Bloom, 4500S, MSS-6132

2. E. Lara-Curzio, 4515, MS-6069

3. P. J. Hadley, 4500 S, MS-6161

4. D. R. Johnson, 4515 , MS6066

5. C. T. Liu, 4500 S, MS-6115

6. P. J. Maziasz, 4500S, MS-6115

7. T. E. McGreevy, 4500 S, MS-6155

8. Office of Technical Information \& Classification, 6011, MS-6283

9. T. M. Rosseel, 4500S, MS-6161

10. D. P. Stinton, 4515 , MS-6065

11. R. W. Swindeman, 4500S, MS-6155

12. K. M. Wilson, $4500 N$, MS-6196

\section{External Distribution}

13. P. F. Browning, Solar Turbines, Inc., Manager - Overhaul Project Management, DeSoto Overhaul Facility, 215 Centre Park Blvd, DeSoto, TX 75115

14. P. A. Carpenter, $4500 N$, MS-6269

15. Sidney Diamond, DOE, EE-2G, 1000 Independence Ave., S.W., Washington, D.C. 20585

16. M. E. Frary, Massachusetts Institute of Technology, Room 8-006, 77 Massachusetts Ave., Cambridge, MA 02139-4307

17. M. J. Pollard, Caterpillar, Inc., Technical Center E, Mossville, Il 61552

18. C. W. Siebenaler, Caterpillar, Inc., Technical Center E, Mossville, IL 61552

19. DOE-WFO,1000,MS-6266 
